\title{
Factors Affecting Different Wheat Varieties Yield in District Pesha- war, Khyber Pakhtunkhwa, Pakistan: A Comparative Analysis
}

\author{
Inam Ullah $^{1}$, Mahfooz Khan ${ }^{2}$, Munir Khan ${ }^{2}$, Himayatullah Khan $^{2}$ and Azra ${ }^{3}$
}

${ }_{1}^{1}$ Abasyn University, Peshawar, Khyber Pakbtunkhwa, Pakistan; ${ }^{2}$ Institute of Development Studies (IDS), The University of Agriculture, Peshawar, Khyber Pakhtunkhwa, Pakistan; ${ }^{3}$ Department of Economics, Kohat University of Science and Technology, Kohat, Khyber Pakbtunkbwa, Pakistan.

Abstract | Wheat is an important grain crop in Pakistan. Despite the fact, that it plays a vital role in country's
economy. However, wheat productivity in Pakistan still is very inadequate due to some reasons. The present
study is focused on inputs used by the wheat growers and its effect on the output of three wheat crops varieties
per hectare. Primary data were collected from 150 selected respondents randomly in district Peshawar. For
this purpose, the effect of various inputs was separately analyzed using multiple regression model. The
empirical results show that for Pirsabaaq-5 wheat variety, the effect of (weedicides) was insignificant. While
for Pirsabaaq-8 wheat variety irrigation was found insignificant and for Pirsabaaq-13, wheat variety the effect
of seed was insignificant. It was observed that majority of the farmers were illiterate and do not apply the
recommended amount of inputs due to its high prices/lack of availability of irrigation water. It is recommended
that respondents should be encouraged to get training from the concerned Agricultural Research Centre in
order to apply the recommended amount of inputs. The government should also provide inputs on subsidized
rates and make irrigation water available through initiating different projects.
Received | June 13, 2019; Accepted | September 30, 2020; Published | October 14,2020
*Correspondence $\mid$ Mahfooz Khan, Institute of Development Studies (IDS), The University of Agriculture, Peshawar, Khyber Pakhtunkhwa,
Pakistan; Email: msmahfoz@yahoocom
Citation | Ullah, I., M. Khan, M. Khan, H. Khan and Azra. 2020. Factors affecting different wheat varieties yield in district Peshawar, Khyber
Pakhtunkhwa, Pakistan: A comparative analysis. Sarbad Journal of Agriculture, 36(4): 1063-1066.
DOI | http://dx.doi.org/10.17582/journal.sja/2020/36.4.1063.1066
Keywords | Wheat varieties, Wheat yield, Inputs, Cobb Douglas production function

\section{Introduction}

I n Pakistan's economy agricultural sector plays an important role. Agriculture sector emerges development in any agricultural based economy in many ways; it provides food to the population and also provides raw materials to the industry. A large number of people of the country depend on farming in the mean of fabrication, processing and supplying of agricultural products.

The contribution of the agricultural sector to the GDP has gradually declined since Pakistan came into existence in 1947. During 1949-50 its contribution to
GDP was more than 50\%, which gradually declined to about $39 \%$ in $1969-70,29.6 \%$ in $1979-80$ and to $24.5 \%$ in 1996-97. In 2013-2014 it share was further decreased to about 20\% (Anjum and Sgro, 2017). Agriculture sector is absorbing a large number labor force. In 1951 agriculture sector was providing directly or indirectly jobs to $75.5 \%$ of Pakistan population, which reduced to $74.5 \%$ in 1961 .Gradually the rate of employment in agricultural sector of Pakistan reduced to $45.1 \%$ in $2010-11$ and remained only $42.3 \%$ in $2015-16$ (Ghazi, 1968).

Agricultural sector of Pakistan has passed through many developmental stages. In earlier period the 
agricultural sector of Pakistan was mainly based on traditional methods. Farmers were not familiar with the use of appropriate amount of different kind of inputs like, chemical fertilizers, insecticides/ pesticides tub-well irrigation, mechanization (i.e. tractor, thrasher etc.) and so on and this was given the name of "Improved Technology". With the adaptation of "Improved Technology" the agricultural sector got a progressive moment and, in the literature, it is known as "Green Revolution" (Evenson et al., 2005). The important characteristics of the "Improved Technology" were that it requires the timely application of chemical fertilizers, mechanization and irrigation water (Leslie, 1972). Adequate and timely availability of chemical fertilizer, irrigation water use of appropriate amount of weedicides can greatly help the farmers to enhance their wheat productivity.

Due to non-application of appropriate amount of inputs the average wheat yield of the Pakistani's farmers is very low. The average wheat yield in Pakistan is about $2800 \mathrm{~kg} /$ hectare (GoP, 2017), in India average wheat output is about $3130 \mathrm{~kg} / \mathrm{hectare}$ and in Egypt it is nearly $7000 \mathrm{~kg} /$ hectare (FAOSTAT, 2015). Keeping in view FAO Statistics 2015, it can easily be deduced that wheat yield in Pakistan is much lower than that of the countries having more or less similar environment. If Pakistani's farmers apply the required amount of different amount of inputs to their wheat crop, their crop productivity will definitely be enhanced. As such increase in productivity is one of the important issues for the researchers in the country.

\section{Materials and Methods}

\section{Study area}

The data was collected by the author during a research conducted in the year 2017-18 to know the effect of different inputs i.e., fertilizer, number of irrigation, weedicides and amount of seed on wheat productivity of the farmers in District Peshawar.

\section{Collection of data}

Primary data was collected from farmers sowing the wheat variety pirsabaak-5, pirsabaak- 8 and pirsabaak-13 through a pre tested interview schedule, a total of 150 farmers were contacted at random, (50 for each variety).

The data was arranged, tabulated and analyzed to know the effect of each and every input on the wheat yield by running regression model using Microsoft Excel and SPSS computer software packages.

To determine the effect of the variables on wheat production, the Cobb-Douglas production function was finally estimated because of the best fit of the sample data (Sarkar et al., 2010).

\section{Analytical technique}

The Cobb Douglas production function was applied General form of the Cobb-Douglas production function may be expressed as follow:

$$
Y_{d=} b_{0} X_{1}^{b 1} X_{2}^{b 2} X_{3}^{b 3} X_{4}^{b 4} e_{i}^{u}
$$

The Cobb-Douglas production function was linearized by transforming it into the following double log form so that it could be solved by the least squares method.

$$
\begin{gathered}
\log Y=\log \left(b_{0}+b_{1} X_{1}+b_{2} X_{2}+b_{3} X_{3}+b_{4} X_{4}+e\right) \text { OR } \\
\log Y_{d}=b_{0}+b_{1} \log X_{1}+b_{2} \log X_{2}+b_{3} \log X_{3}+b_{4} \log X_{4}+e_{i}
\end{gathered}
$$

\section{Whereas;}

$\mathrm{Y}_{\mathrm{d}}=$ wheat yield; $\mathrm{b}_{0}=\log$ of $\mathrm{b}_{0}$ (constant $/$ intercept $) ; \mathrm{b}_{1}$ ${ }_{4}=$ Slope coefficients of associated variables (i.e. output elasticities of associated variables); $\mathrm{X}_{1}=$ seed per hectare; $\mathrm{X}_{2}=$ number of irrigation/hectare; $\mathrm{X}_{3}=$ fertilizer in $\mathrm{kg} /$ hectare; $\mathrm{X}_{4}=$ weedicides $/$ hectare; $\mathrm{e}_{\mathrm{i}}=$ error term.

\section{Dependent variable $=$ Rice Yield (Rs. /acre)}

Independentvariables $=$ cost of various inputs including seed, fertilizer, weedicides, number of irrigations.

\section{Results and Discussion}

Regression model was used for all the three varieties to know effect of each input on the productivity of each variety.

\section{Regression model for variety Pirsabaaq-5}

The effect of inputs on output of the variety Pirsabaaq- 5 is estimated as:

Table 1: Inputs share to wheat variety pirsabaaq-5/ bectare.

$\begin{array}{lllll}\text { Variables } & \text { Coefficients } & \text { Std. error } & \text { t-value } & \text { Sig. } \\ \text { Constant } & 3.100 & 0.090 & 34.534 & 0.000 \\ \text { Seed }(\mathrm{kg}) & 0.128 & 0.050 & 2.574 & 0.013 \\ \text { No. of irrigation } & 0.095 & 0.019 & 5.101 & 0.000 \\ \text { Fertilizer }(\mathrm{kg}) & 0.090 & 0.039 & 2.297 & 0.026 \\ \text { Weedicides }(\mathrm{kg}) & 0.001 & 0.015 & 0.080 & 0.936\end{array}$

Source: Field survey, 2018. 
The above estimated coefficients of the model explain that all the inputs, amount of seed, irrigation and fertilizer have significant effect on respondents' output at $5 \%$ level of significance, while effect of weedicides was found insignificant. In other words, one percent increase of seed use lead to increase in output of the respondents by $0.128 \%$, keeping all other variables constant. Similarly, one percent increase in the use of fertilizer will enhance output of the respondents by $0.090 \%$ and one percent increase of irrigation will enhance output of the respondents by $0.095 \%$. The value of $\mathrm{R}^{2}$ is 0.813 which means that $81.3 \%$ variation in the dependent variable is covered by the independents variables included in the model. The value of $F=48.765$ with $p=.000$ which implies that the overall model is good fitted. The results of Hassan et al. (2010) indicate that the coefficient off seed is positive and significant at 5 percent. It concludes that results are similar.

Regression model for variety PirSabaaq-8

The effect of inputs on output of the variety Pirsabaaq- 8 is estimated as:

Table 2: Inputs share to wheat variety Pirsabaaq-8/ Hectare.

$\begin{array}{lllll}\text { Variables } & \text { Coefficients } & \text { Std. error } & \text { t- value } & \text { Sig. } \\ \text { Constant } & 2.404 & 0.212 & 11.338 & 0.000 \\ \text { Seed }(\mathrm{kg}) & 0.262 & 0.108 & 2.429 & 0.019 \\ \text { No. of irrigation } & 0.085 & 0.044 & 1.942 & 0.058 \\ \text { Fertilizer }(\mathrm{kg}) & 0.268 & 0.071 & 3.798 & 0.000 \\ \text { Weedicides }(\mathrm{kg}) & 0.130 & 0.047 & 2.735 & 0.009\end{array}$

Source: Field survey, 2018

The estimated model explains that all the inputs except irrigation have significant effect on respondents' output. The input seed is significant at 5\% level and shows that one percent increase of seed use, remaining all other variables constant, will increase the wheat output of the respondents by $0.262 \%$. Similarly, fertilizer is significant at $1 \%$ level, one percent of increase in the use of fertilizer has increases output by $0.268 \%$, and one percent increase in the use of weedicides will enhance the output by $0.130 \%$ and is significant at $1 \%$ level. The value of $\mathrm{R}^{2}$ is 0.760 which means that $76.0 \%$ the variability in the dependents variableis explained by the independents variables. Similarly, the value of $F=35.545$ shows that the overall model is significantly fit. Similarly, Rao and Ketema (2016) also revealed that fertilizer has significant and positive effect on wheat yield.

Regression Model for variety PirSabaaq-13

The effect of inputs on output of variety Pirsabaaq-13 of the respondents is estimated as:

Table 3: Inputs share to wheat variety pirsabaaq-13/ hectare.

$\begin{array}{lllll}\text { Variables } & \text { Coefficients } & \text { Std. error } & \text { t- value } & \text { Sig. } \\ \text { Constant } & 2.542 & 0.244 & 10.401 & 0.000 \\ \text { Seed }(\mathrm{kg}) & 0.092 & 0.119 & 0.773 & 0.443 \\ \text { No. of irrigation } & 0.177 & 0.051 & 3.492 & 0.001 \\ \text { Fertilizer }(\mathrm{kg}) & 0.356 & 0.061 & 5.867 & 0.000 \\ \text { Weedicides }(\mathrm{kg}) & 0.200 & 0.070 & 2.862 & 0.006\end{array}$

Source: Field survey, 2018

The estimated coefficients of the model explain that all the inputs have significant effect on respondents' output except seed. Fertilizer, weedicides and number of irrigation are significant at 1\% level. One percent increase in the use of irrigation will enhance the output by $0.177 \%$, keeping all other inputs constant. Likewise, keeping all other inputs constant, one percent increase in the use of fertilizer will push up the output by $0.356 \%$, and one percent increase in the use of weedicides will enhance the output by $0.200 \%$. The value of $\mathrm{R}^{2}$ is 0.861 which means that $86.1 \%$ of the variability in the dependents variable is explained by the independents variables included in the model. Similarly, the value of $F=69.398$ which shows that the overall model is significantly fit.

\section{Conclusions and Recommendations}

The results of the estimated model shown that it is clear that almost all the factors studied in this study have a significant effect on productivity of the three wheat varieties. It is concluded that majority of the farmers are uneducated and do not apply the recommended amount of inputs. As such their wheat productivity is low. Therefore, the following recommendation is forwarded for enhancement for productivity to bring abreast output of the farmers to that of the research station.

- Necessary training programs are required for the farmers and to realize them to use of appropriate amount of inputs.

- Majority of the farmers in research area are uneducated, therefore they are to be encouraged to get education. All possible facilities are to be 
provided to them to get education.

- Farmers should be encouraged to use financial support of commercial banks and ZTBL for purchasing inputs and also to make available irrigation water by installation of tube wells.

\section{Novelty Statement}

The present study is focused on inputs used by the wheat growers and its effect on the output of three wheat crops varieties i.e. Pirsabaaq-5, Pirsabaaq-8 and Pirsabaaq-13.

\section{Author's Contribution}

Inam Ullah: Principal author, conducted research, collected data.

Mahfooz Khan: Helped in research and wrote first draft of the manuscript.

Munir Khan: Helped in data analysis.

Himayatullah Khan: Provided technical guideline.

Azra: Helped in overall format.

\section{Conflict of interest}

The authors have declared no conflict of interest.

\section{References}

Akhtar, M.R., 1988. Farmers' low and high yielding wheat technologies: Cotton zone of the Punjab. Pak. J. Agric. Res., 9(3): 321-324.

Anjum, M.I. and M.P. Sgro. 2017. A brief history of Pakistan economic development. Real-World Economic., 80: 171-178.

Evenson, R.E., Z. Altaf and K.A. Malik. 2005. The green revolution and the gene revolution in Pakistan: Policy implications. Pak. Dev. Rev., pp. 359-386. https://doi.org/10.30541/
v44i4Ipp.359-386

FAOSTAT, F. 2015. Food and Agriculture Organization of the United Nations Statistics Division. Rome, Italy.

Ghazi, D. 1968. Economic development in Tunisia. New York. Praeger 1967.

Hassan, I., M.B. Chattha, T.H. Chattha and M.A. Ali. 2010. Factors affecting wheat yield: A case study of mixed cropping zone of Punjab., Pak. J. Agric. Res., 48(3): 403-408.

Leslie, N., 1972. The green revolution in West Pakistan: Implication of technological change. Pak. Eco. Soc. Rev., 11(4): 473-477.

GoKP, 2016. Crop statistics and crop reporting services. Agriculture and Livestock Department, KP, Pakistan.

GoP, 2011. Economic survey of Pakistan 2010011. Ministry of finance and economic advisory wing. Islamabad, Pakistan.

GoP, 2015. Economic survey of Pakistan 201115. Ministry of finance and economic advisory wing. Islamabad, Pakistan.

GoP, 2017. Economic survey of Pakistan 201617. Ministry of finance and economic advisory wing. Islamabad, Pakistan.

GoP, 2018. Economic survey of Pakistan 201718. Ministry of finance and economic advisory wing. Islamabad, Pakistan.

Rao, A.L. and H. Katema. 2016. Statistical analysis of factors affecting wheat production, A case study of Walmara Woreda. Int. J. Engeer. Manage Res., 6(5): 43-53.

Sarkar, M.S.K., M.R. Hasan, M.A. Feardous, M.M.H. Shuhel and Moniruzzaman. 2010. Comparative economic analysis of borrower and non-borrower Boro rice farmers in some selected sites of Mymensingh, district, Bangladesh., J. Agric. Res., 35(1): 65-76. https://doi.org/10.3329/bjar.v35i1.5867 